\title{
The Nature of Authority and Employee Participation in the Management of Academic Libraries
}

\section{Charles Martell}

Power and control are central forces in organizational life. Some researchers have even concluded that the control of behavior is often substituted for control of outcomes. This practice could lead managers to ignore relevant environmental changes in favor of strategies that reinforce and enhance their personal self-interests. This article examines the nature of authority as embedded in organizational and professional structures within an academic library context and its relationship to the fit between the organization and the environment. Who makes decisions about what is a key factor in how control is maintained? Traditional theories of management circumscribe the extent of employee participation in decision making. In practice, this may lead managers to limit participation because it threatens their control. In a dynamic environment, however, this strategy could be dysfunctional. Two alternative forms of decision making are introduced: self-regulation and formal participation.

The subject was corporate transfer assignments. As the vice president for personnel turned to a map of the United States located on the wall, he remarked that employee transfers were simple. "All I have to do is lift a pin here in White Plains and place it in San Francisco. That's all there is to it." Shortly thereafter my interview for a sales/marketing position at General Foods concluded.

Because he rejected any personal or family considerations that might be involved in such transfers, I felt that the executive's remarks were callous. Today $I$ also realize that he expected me to give him the power to control not just my work life but my personal life as well.

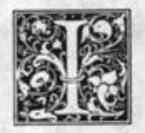

$\mathrm{n}$ academic librarianship our experiences with power are not usually so blatant. Power and control are, however, central forces in organizational life. ${ }^{1,2}$ Indeed, some researchers view the control of be- havior as a primary goal of traditional organizational structures. ${ }^{3}$ This is surprising since the most commonly held belief is that these structures are mainly oriented toward the control of outcomes, i.e., toward better products and services. In libraries, the desire to protect sources of power and control within the organization may lead some major stakeholders to ignore or minimize the needs of external constituencies. ${ }^{4}$

To counter the negative manifestations of power and self-interest, new forms of involvement, such as self-regulation and formal participation, could be adopted by organizations (1) to focus attention on the development of better products and services rather than on the control of behavior, (2) to decentralize power so that a more equitable balance of interests can be

Charles Martell is Associate University Librarian for Public Services at California State University, Sacramento, California 95819. 
achieved, and (3) to change authority structures so that members throughout the organization can contribute to the decision-making process in a more meaningful way.

This article examines the nature of authority as embedded in organizational and professional structures within an academic library context and the relationship of these factors to the fit between the organization and its environment. Special attention is focused on how various structures may inhibit responsiveness to environmental changes. The concept of power is treated next. The third section explores decision making, and in the final section two alternative forms of decision making are introduced: self-regulation and formal participation. If adopted, these alternative forms would necessitate changes in authority relationships and in the design of the organization.

\section{ORGANIZATIONAL STRUCTURES}

An organization is an open system. Its members interact with one another and with an outside system-an external environment. ${ }^{5}$ The variety of self-interests, perceived goals, and environmental demands usually leads to a multiplicity of often competing goals within the organization.

In theory, the organizational structure, that is, the formal pattern of roles and relationships, provides a common sense of purpose and direction so that diverse interpersonal, organizational, and environmental demands can be more efficiently reconciled. Complexity and uncertainty complicate the decision-making process and hinder agreement on goals. As a result, and in contrast to the past, there may be less internalization of workrelated norms. This increases the difficulty of planning, directing, and controlling organizational outcomes.

Viewed in terms of classic organizational theory, the lines of authority and responsibility in libraries emanate downward from the head librarian through a process called delegation. Managers thus empowered control resources, access to information, and information itself. They also control decision-making processes?
In theory, this hierarchical structure provides a basis for effective decision making. ${ }^{8}$ In practice, the structural hierarchy may constrain the decision-making opportunities of those who do not have formal authority or responsibility. ${ }^{9}$ Moreover, this system may encourage individuals in positions of responsibility to stress control of behavior through rules, evaluation, and the structure itself. The control of outcomes may become secondary. This would increase the likelihood of a mismatch between the organization and its environment.

In their book, Organization and Environment, Paul Lawrence and Jay Lorsch look at the problem of how "different external conditions might require different organizational characteristics and behavior patterns within an effective organization." 10 Mismatches occur when organizations are insensitive toward or otherwise fail to respond to relevant environmental shifts.

According to Lawrence and Lorsch, organizations structured along traditional lines are most successful when conditions are stable. In dynamic or turbulent environments, they tend to be overly rigid. In such environments, less hierarchical systems that encourage participation are characteristically more adaptive and successful.

The structures that we confront at work may constrain the scope of our actions and may limit responsiveness to users. ${ }^{11}$ How can we escape this bind? At the very least we can adopt a more critical posture toward these major structures, both organizational and professional. ${ }^{12}$ This would allow us to distinguish more clearly between those aspects of the structure that benefit our users and meet our obligations to the environment and those aspects of the structure that constrain such action.

\section{Organizational/Environment $(\mathrm{O} / \mathrm{E}) \mathrm{Fit}$}

Significant organizational changes have occurred in libraries in recent years. Some have been driven by automated technologies that unleashed a revolution in technical service operations. Nevertheless, any monitoring of the library's responsiveness to relevant changes in user needs has been 
slow to develop. Why? In an environment that most observers call turbulent and uncertain, why have libraries not taken more direct action to increase their adaptive capacity through the creation of more useroriented structures? Fiscal shortages can be cited, but we should also seek less obvious factors because the passive service orientation identified by Gardner Hanks and C. James Schmidt also existed during periods of fiscal strength. ${ }^{13}$

Three key factors emerge. First, as a rule, academic librarians pay little attention to environmental monitoring. Charles McClure finds that library middle managers generally distrust statistical measures and believe that such measures are ineffective as indicators of the quality of public services. ${ }^{14}$ These attitudes and behaviors persist despite the general acceptance of an open-systems model of organizing that stresses the close ties between the organization and its external environment and the critical importance of empirical feedback. ${ }^{15}$

Second, sociologists have noted the tendency of organizations to view the environment as alien and hostile and to treat clients as problems that interfere with the organization's efforts to create uniformity and order. ${ }^{16}$ Jeffrey Pfeffer and Gerald Salancik suggest that

Organizations may purposely manipulate the illusion of satisfaction to avoid the open expression of some demands. Patients in a psychiatric hospital may be drugged to reduce their demands on the staff. At the same time, relatives may be told about all the fine therapeutic activity going on. ${ }^{17}$

Hanks and Schmidt note the sometimes hostile reaction of our profession to direct user input. They offer suggestions for improving the design based on clientcentered principles. ${ }^{18}$

Changes in the design of academic libraries are probably necessary if significant improvements are to occur in the organizational/environmental fit. These changes would quite naturally include the organizational structure. However, structural changes that would threaten privileged interests or status would meet resistance.
Organizational participants are in a contest for resources and their control. This contest is political and is fought in many contexts within organizations. One context is the structural arrangement of positions and persons within organizations. Design is an important factor affecting who controls organizations, who governs. ${ }^{19}$

Here we have the third key factor that may limit the responsiveness of academic libraries to user needs: the self-interest of dominant officeholders and employee groups.

Some researchers view the excessive reliance on structure as a mechanism for protecting self-interests and organizational prerogatives. In this context organizational change is threatening because it may alter authority relationships. Walter Nord suggests that major stakeholders "seek to protect their interests and positions of influence by moderating environmental pressures and their effects. ${ }^{\prime 20}$ Protective measures may take an even more active form as stakeholders seek and promote those changes that will reduce the discretionary decision-making power of other organizational members. This practice would be especially dysfunctional in dynamic environments that demand higher degrees of power sharing and increased responsibility with improved access to resources and information for members at lower levels in the hierarchy.

\section{PROFESSIONAL STRUCTURES}

Any examination of the nature of authority in academic librarianship should address professional structures, or the elements that produce and support a professional interest group in the library through both intra- and interinstitutional mechanisms, as well as the impact of these structures on organizational outcomes. This approach is recommended to redress weaknesses in the professional model of librarianship described by Hanks and Schmidt, and to counter recurring critiques of the professions by sociologists. ${ }^{21}$

Robert Reiff finds that professionals act as if "the basis of professional power is not knowledge itself but the control of knowledge." 22 As a result, members of professions may be reluctant to share their 
skills with the client, because they believe "the more knowledge the public acquires, the less firm the basis of the authority granted. ${ }^{\prime 23}$ Professional control in this sense may be extended not only to clients but also to other employee categories. Hanks and Schmidt highlight related weaknesses: (1) a tendency to restrict, discourage, and overlook interaction with the user environment; (2) elitism that fosters status differentials within the library between professional and nonprofessional employees; and (3) the potential negation of the concept of community service by other elements of the model. Negation occurs when the pursuit of attributes such as professional autonomy becomes self-serving and gains for librarians are made at the expense of the user. ${ }^{24}$

Robert Veatch's analysis of medical ethics leads him to conclude that professionally articulated codes are ethnocentric and do not relate to the needs of ordinary people. In the early 1970 s, members of a graduating class from the Harvard Medical School refused to take the Hippocratic Oath because it neglected to mention the rights of patients, to acknowledge social responsibilities, and to face the issues of justice, equity, liberty, and autonomy. ${ }^{25}$ Fortunately, the Librarians' Code of Ethics, adopted by the Council of the American Library Association (June 30, 1982), is a noteworthy document that stresses service, social responsibility, due process, and equality of opportunity. ${ }^{26}$

There is little reason to believe, however, that the code exerts a strong influence on the day-to-day behavior of librarians. The pressures of self-interest are strong and so we must remain skeptical. Certain aspects of authority as embedded in professional and organizational structures may constrain our service orientation until changes in libraries lead to the modification of authority relationships. ${ }^{27}$

\section{POWER: ITS USES AND MISUSES}

The actions of management have legitimacy because we commonly assume that they are taken for the good of the organization and its clients. ${ }^{28}$ This assumption can disguise negative manifestations of power. ${ }^{29}$ Samuel Bacharach and Edward J. Lawler, for example, suggest that "organizational life is dominated by political interactions; politics in organizations involve the tactical use of power to retain or obtain control of real or symbolic resources. ${ }^{\prime 30}$ From this perspective, organizational decisions are often made to reinforce the status and prestige of individuals internally rather than to provide better products or services. Furthermore, changes to benefit users may be opposed because they interfere with internal sources of power. ${ }^{31}$ This practice could impair the organization's ability to adapt effectively to environmental changes, and thus could lead to mediocre standards of service.

If staff conclude that the use of power at the managerial level has a deleterious effect on the rationality of the decisionmaking process, a reduction in the legitimacy accorded to management might occur. ${ }^{32}$ Staff attempts to offset or to cope with the negative dimensions of power or self-interest could lead to the growth of informal decision-making channels. Staff who dramatize weaknesses in the organization's service orientation, however, expose themselves to the coercive and punitive power of officeholders.

Power is a complicated phenomenon that continues to intrigue theorists in the fields of economics, political science, and organizational behavior. In libraries the lines of authority and responsibility create a structure that governs (1) who sets the goals, (2) how resources are allocated, (3) who makes decisions about what, (4) who evaluates, (5) who benefits, (6) who is to do what, and (7) what means are to be used. Because authority allows the officeholder to exert influence through control over resources and information, the structure bestows power.

The misuse of power in the organizational setting and the relative inflexibility of both organizational and professional structures have led some researchers to examine alternative forms of power distribution. ${ }^{33}$ Traditional theories of distribution state that power emanates from the top of the administrative hierarchy which has an absolute right of delegation. Power 
is treated as a fixed quantity (power = amount of influence + amount of control). ${ }^{34}$ Thus, any manager who allows a subordinate to make a decision experiences a net loss of power or influence. Or more simply, for every winner there is a loser.

Current research emphasizes an expanding quantity of power. Studies at the Institute for Social Research at the University of Michigan indicate that the "total amount of power is generally a more effective predictor of organizational productivity and organizational morale than the hierarchical distribution of power. ${ }^{\text {35 }}$

\section{DECISION MAKING}

Effective decision making is an important theme in the field of organizational behavior. ${ }^{36}$ In libraries, effective decision making should result in the ability to satisfy user needs over time, to help users make new sense for themselves in a variety of situations, to provide a satisfying and rewarding work experience for all staff, and to obtain the resources necessary to meet the three criteria stated above. ${ }^{37}$ However, sufficient evidence exists to question the adequacy of traditional structures and the decision-making processes that characterize them.

Among the factors that have led researchers to conclude that we need new structures are the following: the effect of self-interest; the lack of agreement on goals; the deterioration of our formerly internalized system of shared norms and values; decision complexity; the rate and scale of change, organizational size, technological advances; the higher educational levels of the workforce; social, cultural, and personal needs; and a broadened base for the expansion and attainment of various rights. Nevertheless, progress toward new structures has been slow.

A survey of library literature in the areas of organizational structure, decision making, participation, and power was undertaken in order to guide further discussion. ${ }^{38}$ Ten findings of this survey are cited here:

- There is a general acceptance of traditional bureaucratic forms but the discus- sion of alternative forms has expanded in the 1980s.

- Traditional views of authority and responsibility are usually accepted without question.

- The concept of power is seldom used, and the influence of power on the decision-making process is accordingly neglected. An article by Richard Eggleton on choice-shift strategies and articles by Louis Kaplan on decision sharing are two exceptions. ${ }^{39}$

- Power is treated as a fixed rather than an expanding factor. This provides one explanation why traditional forms of organizing remain entrenched.

- The potential dehumanizing effect of an unequal distribution of power in academic libraries is rarely mentioned.

- A narrow view persists of the forms of participation possible in our libraries. Self-regulation and formal participation, i.e., the right to participate as distinct from privilege or delegated authority, are novel concepts.

- Definitions of participation and the subject of participative management are treated as relatively simple phenomena when, in fact, they are extremely complex.

- The decision to permit or to deny participation is treated as a managerial right. Participation is viewed as a managerial tool or strategy. Management is free to determine (1) if participation will be permitted, (2) at what stage in the decisionmaking cycle participation will occur, (3) what the degree of participation will be, (4) who will participate, (5) within what time-frame participation will take place, and (6) what will be done with the product of the participation.

- Decision making is discussed as a discrete event. There is little comment on the interrelationship of decisions over time.

- There is no comprehensive framework for staff involvement in decision making from the problem identification stage through the implementation stage.

For the library to be responsive to its users, it is necessary to recognize when the users' environment has changed. Once a 
change occurs and is recognized, the next issue becomes what to do. Ideally, this involves a statement of the problem, the generation, consideration, and choice of alternatives, and finally, implementation. Quality decisions are enhanced, therefore, by a combination of environmental monitoring and attention to the several stages in the decision-making cycle. ${ }^{40}$

\section{Influences on the Quality of Decision Making}

In principle, libraries pursue a set of goals that serve to direct the actions of staff. It is assumed that there is agreement on goals and a cohesive framework of shared understandings. From this implicit consensus, management can build a reasonable case that it upholds and advances the interests of users, staff, and other constituent groups. In practice, a multiplicity of goals exists and the value structures underlying them are widely divergent. ${ }^{41}$ Accordingly, goal congruence may be atypical and unresolved conflict may predominate. The tendency to avoid the examination of different value structures and professional or institutional goals may force organizational participants to increase their pursuit of self-interest.

Rosemary Du Mont notes that "the lack of agreement on the significance of various techniques [i.e., approaches to viewing library effectiveness] poses a serious problem both for library administrators and for analysis of the library as an organization; it makes it difficult, if not impossible, to evaluate a library's success or failure adequately." ${ }^{\prime \prime 2}$ If management is unable to demonstrate meaningful progress because of the lack of goal congruence, staff might conclude that selfinterest rules and that an active orientation toward users is the victim. This could undermine the legitimacy accorded to management. Staff might infer that more direct participation in decision making would moderate and perhaps correct weaknesses in leadership. ${ }^{43}$

Lack of agreement on library goals and on what constitutes library effectiveness can lower the quality of decision making. If poor choices are made when considering the appropriate decision-making structures to address a problem, quality can be further eroded. ${ }^{44}$ Use of inappropriate structures can lead to a solution with limited innovative capacity (rigid search behavior) and low commitment (lack of staff participation in decisionmaking process). ${ }^{45}$ Building ownership into decision outcomes can facilitate the implementation process by reducing the incidence of low commitment. ${ }^{46}$

\section{PARTICIPATION: PLACEBO OR PANACEA}

Employee participation in decision making was a widely discussed issue in the 1970s. Opinions on the degree of participation to be permitted ranged from zero to 100 percent. In practice, the show-and-tell style of management so prevalent in the past has been replaced by a more consultative style. Social changes external to libraries are partially responsible for the adoption of a new style. Many individuals now feel entitled to more legitimate input into the decision-making process. Management education has also changed, and employee involvement in decision making is encouraged. ${ }^{47}$

Because decision making is increasingly complex, managers are being forced to rely more and more on the judgment and expertise of employees lower in the organizational hierarchy. ${ }^{48}$ Nevertheless, the classic principles of ultimate responsibility and delegation of authority persist. ${ }^{49}$ Formal participation is not viewed as an employee right. According to Peter Dachler and Bernhard Wilpert, "one can hardly consider as an historical accident the fact that existing participatory systems in the United States, for example, characteristically limit the access of participants to the decision-making process, restrict the range and importance of decisions to be included in the participatory system, tend to be direct and informal, and usually involve a limited social range."

In academic librarianship the role of staff in decision making varies widely. ${ }^{51}$ In addition, strong differences of opinion exist between professional and nonprofessional staff, just as they do between the professional staff and the library administration. ${ }^{52}$ For example, Dennis Dickinson 
calls for centralized decision making because only those in upper-level positions "perceive and understand the organization as an integrated whole."

The consultative approach decentralizes the deliberative process but does not necessarily change who makes the final decision: it may merely formalize the advisory role. The effectiveness of the consultation in terms of staff interest can be determined by the number of times that the advice given on important issues is acted upon in proportion to the number of times it is not. Because consultation is a procedural and not a structural change, the sources of power remain almost the same.

In consultative systems, the manager retains an enormous capacity to influence outcomes. Lammers cites five ways in which managers can obstruct joint consultation:

1. Use joint consultation for downward but not upward communication.

2. Treat members of a group not as representatives but as individual employees expressing personal opinions.

3. Send lower-level supervisors to meetings thereby lowering the hierarchical level on which groups can exert influence.

4. Deal only with unimportant matters.

5. Keep a free hand by not cooperating in drafting bylaws or by refusing to keep official or detailed minutes. ${ }^{54}$

Weaknesses in the decision-making processes of organizations have led some to conclude that managers should adopt a less supervisory and more coordinative role. ${ }^{55}$ In contrast to the win-lose, zerosum gain calculations of traditional power theorists, such a change in managerial style could lead to a power gain for all participants. Lammers has demonstrated how the amount of influence available to any organization has the potential to expand constantly if structures free the employee to participate more in decision making. ${ }^{56}$ An alternative view is that participation and power are so closely related that managers would only relinquish their current status and controlling influence if forced to do so.

Decision sharing is one form of participative management. ${ }^{57}$ It goes well beyond management by consultation. For this type of decision making to work, managers must avoid the creation of mock participative situations such as the five methods for obstruction cited above. Otherwise, employees will soon realize that the actual sources of power are unchanged and may resort to action that causes a deterioration of the organization's effectiveness. ${ }^{58}$

The work of Dachler and Wilpert, "Conceptual Dimensions and Boundaries of Participation in Organizations: A Critical Evaluation," is a significant contribution to the literature on participation. The authors discuss "the social theories underlying participatory social systems and the values and goals each of them implies for participation, the major properties of participatory systems, the outcomes of participation in organizations, and the contextual characteristics of participatory system which limit or enhance their potential. ${ }^{159}$ They list four social theories:

1. Human growth and development theory

2. Productivity and efficiency orientation

\section{Socialistic theory}

4. Democratic theory

Theories one and two comprise the traditional perspectives that managers use. Human growth and development theory restricts any form of participation to issues surrounding the work itself (employee compensation and benefits, production methods, working time arrangements and hygienic factors such as coffee breaks and furnishings) rather than including issues such as the development and implementation of services, the selection of top management, wage and benefit policy, capital investment, reorganization, and choice of technology. The productivity and efficiency orientation "conforms to a paradigm which seeks an instrumental understanding of human beings and their capacities, and in which people are considered to be manipulable toward maximum output through appropriate social technologies." ${ }^{\prime 60}$ By limiting participation to issues surrounding task accomplishment, the traditional perspectives allow management to maintain control.

Obviously, perspectives on participation differ among the social theories. 
P. Bernstein suggests a means for understanding participation independent of any particular social theory. He uses three dimensions: (1) the degree of control employees have over a decision; (2) the range of issues over which control may be exercised; and (3) the organizational level at which employees' influence is exercised. ${ }^{61}$

\section{NEW RULES, NEW STRUCTURES}

Few library managers subscribe to a value structure that calls for the distribution of organizational authority along democratic lines. Participation is generally viewed not as a right but as a strategy to be used, or as a managerial style. Various forms of direct (face-to-face) participation are used at the workplace or shop level. Although this style of participation is frequent in the United States, it is almost nonexistent in Europe. Instead, the European system of organizational governance stresses participation as a right at the highest levels. Workers participate in national councils and on boards of directors.

Nightingale lists eight degrees of participation:

1. Employees need not be informed about decisions made by management (except as necessary to conduct their work).

2. Employees have the right to be informed after decisions are made.

3. Employees must be informed ex ante and given an opportunity to voice their opinions.

4. Employees are consulted informally before a decision is made.

5. Employees must be consulted before a decision is made.

6. Employees participate informally with management in decision making: management (through "residual rights") and employees (through the collective agreement) retain the right of veto over some issues.

7. Management and employees jointly make decisions. In some cases employee representatives have parity with stockholder and management interests; in others, stockholder and management interests dominate.

8. Employees have the final say in decision making. ${ }^{62}$
Formal participation (as a right) and self-regulation (autonomy) are forms of decision making that conform to the tenets of democratic theory. They also conform to theories of social justice, such as those developed by John Rawls, that "respect impartially the basic interests of participants in social systems. ${ }^{163}$ Here equality includes not only equal treatment but treatment as an equal. By adopting these forms libraries might be able to approach their problems from a healthier and more creative perspective. Employees might also be more challenged and find more meaning in their work. In addition to a new sense of power and competence, the employee might see a stronger connection between the values society espouses and the values it practices. ${ }^{64}$

In New Rules in American Life: Searching for Self-Fulfillment in a World Turned Upside Down, Daniel Yankelovich states: "If the great choices that determine our destiny are made for us by others-by elites, by technicians, by elected officials-then we are not free, though we may be wholly liberated .... an employee in a hierarchical organization is not free within the workplace. ${ }^{\prime \prime 65}$ Equity, fairness, and democracy should have a socially mandated role in the workplace.

\section{Formal Participation}

Formal participation extends the right to participate. Dachler and Wilpert define formal participation as an "explicitly recorded system of rules and agreements imposed on or granted to the organization. ${ }^{\prime \prime 6}$ Nightingale describes it as power sharing with "structural arrangements which give 'formal' and documented decision-making rights to employees. ${ }^{\prime \prime 67}$ Informal participation, on the other hand, is nonstatutory consensus. ${ }^{68}$ The degree of informal participation varies with organizational traditions and managerial styles in use.

Formal participation is legitimated through laws, collective bargaining contracts, and unilateral regulations that direct management action. A few academic libraries have moved in the direction of formal participation. At many institutions staff have direct input into hiring and peer review decisions. Full formal participa- 
tion, however, might include staff involvement in the decisions leading to the adoption and implementation of new services or technologies, determining the allocation of resources, planning new facilties, establishing general policies, setting library budgets, and specifying library faculty assignments. Decisions in these areas are often reserved for top management, whereas staff are likely to make decisions regarding production methods, scheduling, and other work-related arrangements.

The most democratic form of decision making unites formal and direct participation. Direct participation signifies the personal involvement of individual staff members. Indirect participation is not personal but is mediated through some form of representation. Nightingale indicates an important difference between supervising styles that assume employees have the right to participate directly in decision making and those that offer only indirect rights through representation. ${ }^{69}$

Most managers view direct participation as unfeasible or only useful for a narrow range of issues. ${ }^{70}$ Time pressures, lack of expertise, and insufficient information are usually cited as constraints that inhibit the greater involvement of staff in decision making. These constraints can, however, be altered through the adoption of more effective management practices. ${ }^{71}$

There are other important characteristics that can affect the nature of staff participation such as "the degree to which participants have access to the decisionmaking process, the range and importance of issues, and the kind of decision rules to be included in the participatory decision-making process, the range of people or organizational units to be included in direct-participation systems, and the base of legitimacy on which the direct participation system is developed. ${ }^{\prime 72}$

A standard that calls for direct formal staff involvement in all decisions irrespective of the range or importance of issues may be ideal to some; however, the routineness of many decisions precludes strict adherence to such a standard. The actual degree of involvement by staff should be negotiated carefully so that the organization can be adaptable without sacrificing its ability to meet time constraints and can maintain equity without diminishing its effectiveness.

Major changes in the decision-making structure of academic libraries would require corresponding changes in both managerial practice and staff behavior. ${ }^{73}$ Managers would have to move from a direct control mode to a coordinating role. ${ }^{74}$ Moreover, as Dickinson notes, some staff may find it difficult to cope with increased participation. ${ }^{75}$ Formal participation would surely affect the organizational design of the library, because the nature of authority would be altered so dramatically.

\section{Self-Regulation}

Self-regulation in the workplace can be defined as control by the employee over those decisions that directly affect the work to be performed. ${ }^{76}$ Self-regulation occurs most frequently in a team or group setting. The basic design feature is to give individual work groups the tools and resources to operate in a quasi-autonomous manner. Group members make many of their own decisions but do so within broad guidelines developed by the institution, usually in consultation with other members. Self-regulating work groups determine work methods and task assignments. They also handle quality control, scheduling, evaluation, client problems and service enhancements. ${ }^{7}$ This type of advanced work systems design has been developed during the past twenty years. ${ }^{78}$

In The Client-Centered Academic Library, a prototype design is proposed that incorporates the use of self-regulating work groups. ${ }^{79}$ This design also calls for both the redesign of the systems of work and the redesign of the library as an organization. Formal participation and self-regulation are proposed. It provides a consistent and coherent philosophy of staff involvement in decision making throughout the library.

Some researchers have observed a loose coupling between the actual work of the organization and the general structure that develops plans and policies. The theory of parallel organization is based on the 
principle of loose coupling. ${ }^{80}$ The parallel organization does not replace the bureaucratic hierarchy but supplements it. The conventional line hierarchy still performs those tasks for which it is best suited; however, the parallel organization is structured to be more responsive and participatory in problem solving. Flexibility and responsiveness are stressed. One goal of this type of organization is to provide the employee with more challenging and meaningful work. There is also increased employee control through a sense of entitlement, more rights and job autonomy, and less overall supervision. ${ }^{81}$ Barry Stein and Rosabeth Kanter view the parallel organization as one means to reform the traditiona! organization while still taking advantage of traditional capabilities.

Within academic librarianship concerted attention should be paid to alternative work structures and their potential value. In the "Macropolitics of Organizational Change," Robert Cole describes an agenda for research on the comparative analysis of participative organizational forms. ${ }^{82}$ This and other published material provide the profession with an excellent starting point.

\section{CONCLUSION}

There has been steady progress in staff involvement in decision making over the past fifteen years. However, a slowdown has occurred in the 1980s. Part of this may be attributed to reduced staff interest in decision making. It may also be an indication that outstanding staff issues in the 1960 s and 1970 s have been satisfactorily addressed. ${ }^{83}$
Early in the decade the economic situation led management to use staff in solving problems when major shifts in the allocation of resources or cuts in traditional wage and benefit packages were required. Corporate leaders relaxed restrictive work rules in exchange for wage freezes and the deferral of benefits. In distressed industries, management gave unions consultative rights regarding capital outlays and other investment plans, access to confidential data on company costs, expanded employee participation, decision-making involvement on plant and production problems and guarantees against plant closings. ${ }^{84}$

The extension of rights to employees for formal and direct participation in key decision-making areas can provide organizations with a valuable new resource to assist in coping with rapid change and technological complexity. That is, it makes good sense. It can also lead to new organizational designs that make innovative use of decision-making structures and processes. Chris Argyris wrote:

People create streets. Once streets are built, they coerce people to ride on them and not on sidewalks. People can create new streets and alter old ones; streets cannot create new streets. ${ }^{85}$

Analogously, by breaking out of the straitjacket of our traditional organizational structures, we will be able to explore and experiment with new designs. This may help us to cope more effectively with future challenges that now threaten to overload us and that hamper efforts to create more responsive libraries.

\section{REFERENCES}

1. In The Anatomy of Power (Boston: Houghton, 1983). John Kenneth Galbraith describes the uses and misuses of power.

2. Samuel B. Bacharach and Edward J. Lawler, Power and Politics in Organizations: The Social Psychology of Conflict, Coalitions, and Bargaining (San Francisco: Jossey-Bass, 1980); Jeffrey Pfeffer, "Who Governs?" in The Sociology of Organizations: Basic Studies, 2d ed., ed. Oscar Grusky and George A. Miller (New York: Free Press, 1981); Charles J. Fombrun, "Structures of Organizational Governance," Human Relations 37:207-23 (Mar. 1984); and William T. Markham, Charles M. Bonjean, and Judy Corder, "Measuring Organizational Control: The Reliability and Validity of the Control Graph Approach," Human Relations 37:263-94 (Apr. 1984).

3. Jack R. Gibb, Trust: A New View of Personal and Organizational Development (Los Angeles: Guild of Tutors Press, 1978), p.245; Pfeffer, "Who Governs?"; William G. Ouchi, "The Transmission of 
Control through Organizational Hierarchy," Academy of Management Journal 21:173-92 (June 1978); Nestor K. Orville II, "Organizational/Managerial Control Processes: A Reconceptualization of the Linkage between Technology and Performance," Human Relations 37:1047-62 (Dec. 1984); and Steven P. Feldman, "Culture and Conformity: An Essay on Individual Adaptation in Centralized Bureaucracy," Human Relations 38:347 (Apr. 1985).

4. Eliot Freidson, Professional Powers: A Study of the Institutionalization of Formal Knowledge (Chicago: Univ. of Chicago Pr., 1986), p.177.

5. W. Richard Scott, Organizations: Rational, Natural, and Open Systems (Englewood Cliffs, N.J.: Prentice-Hall, 1981).

6. Bacharach and Lawler, Power and Politics in Organizations, p.4; Michael Keeley, "Impartiality and Participant-Interest Theories of Organizational Effectiveness," Administrative Science Quarterly 29:3 (Mar. 1984); and Michael Blumstein, "Executives Being Challenged on Salaries and SelfInterest," New York Times (May 8, 1984), p.Al, D5.

7. George M. Prince, "Creative Meetings through Power Sharing," Harvard Business Review 50:47-48 (July-Aug. 1972).

8. Fombrun, "Structures of Organizational Governance," p.207-23.

9. Walter R. Nord, "Dreams of Humanization and the Realities of Power," Academy of Management Review 3:676-77 (July 1978); Bong Gon Shin and Elliot Zashin, "Management and the New Egalitarianism: McGuire Revisited," California Management Review 24:7 (Summer 1982); and Fernando Bartolome and Andre Laurent, "The Manager: Master and Servant of Power," Harvard Business Review 64:77-81 (Nov.-Dec. 1986).

10. Paul R. Lawrence and Jay W. Lorsch, Organization and Environment: Managing Differentiation and Integration (Homewood, Ill.: Irwin, 1969), p.14.

11. Patricia Riley, "A Structurationist Account of Political Cultures," Administrative Science Quarterly 28:414-37 (Sept. 1983).

12. Gardner Hanks and C. James Schmidt, "An Alternative Model of a Profession of Librarianship," College \& Research Libraries 36:184 (May 1975); and J. Kenneth Benson, "Organizations: A Dialectical View," Administrative Science Quarterly 22:1 (Mar. 1977).

13. Hanks and Schmidt, "An Alternative Model of a Profession of Librarianship," p.177.

14. Charles R. McClure, "A View from the Trenches: Costing and Performance Measures for Academic Library Public Services," College \& Research Libraries 47:323-36 (July 1986).

15. In their article, "Scanning the University's External Environment," in the Jourmal of Higher Education 56:420 (July/Aug. 1985), James C. Hearn and Richard B. Heydinger state that "the ideal organization surveys its environment in general, selects certain key environmental issues, trends, and domains for concentrated tracking, and feeds useful clues into its ongoing strategic decision making."

16. Frederick Fox, Larry E. Pate, and Louis R. Pondy, "Designing Organizations to Be Responsive to Their Clients," in The Management of Organization Design, V.1, ed. Ralph H. Kilmann, Louis R. Pondy, and Dennis P. Slevin (New York: Elsevier, 1976), p.64; and Allen B. Veaner, "'1985 to 1995: The Next Decade in Academic Librarianship, Part I," College \& Research Libraries 46:221-22 (May 1985).

17. Jeffrey Pfeffer and Gerald R. Salancik, The External Control of Organizations (New York: Harper, 1978), p.98.

18. Hanks and Schmidt, "An Alternative Model of a Profession of Librarianship," p.183.

19. Pfeffer, "Who Governs?" p.230.

20. Nord, "Dreams of Humanization," p.676.

21. Pfeffer, "Who Governs?"; Freidson, Professional Powers, p.174; W. J. Reeves, Librarians as Professionals: The Occupation's Impact on Library Work Arrangements (Lexington, Mass.: Lexington Books, 1980); and William J. Goode, "The Librarian: From Occupation to Profession," Library Quarterly 34:306-18 (Oct. 1961).

22. Robert Reiff, "The Control of Knowledge: The Power of the Helping Professions," Journal of Applied Behavioral Science 10:459 (1974).

23. Ibid., p.453. Brian Nielsen arrives at the same conclusion in "Teacher or Intermediary: Alternative Professional Models in the Information Age," College \& Research Libraries 43:188 (Miay 1982).

24. Hanks and Schmidt, "An Alternative Model of a Profession of Librarianship," p.178.

25. H. Jack Geiger, "The Right Medicine," New York Times Book Review (Jan. 31, 1981). A review of A Theory of Medical Ethics by Robert M. Veatch (New York: Basic Books, 1980), p.110.

26. "Librarians' Code of Ethics," American Libraries 13:595 (Oct. 1982). Adopted by the Council of the American Library Association on June 30, 1982.

27. Ralph M. Edwards, "The Management of Libraries and the Professional Functions of Librarians," Library Quarterly 45:156 (Apr. 1975). 
28. Bacharach and Lawler, Power and Politics in Organizations, p.39.

29. David Kipnis, "Does Power Corrupt?" Journal of Personality and Social Psychology 26:33 (Oct. 1972).

30. Bacharach and Lawler, Power and Politics in Organizations, p.1.

31. Nord, "Dreams of Humanization," p.676.

32. Kipnis, "Does Power Corrupt?" p.38; and Shin and Zashin, "Management and the New Egalitarianism," p.12.

33. C. J. Lammers, "Power and Participation in Decision-making in Formal Organizations," American Jourmal of Sociology 73:201-16 (Sept. 1967); and Sar A. Levitan and Clifford M. Johnson, "Labor and Management: The Illusion of Cooperation," Harvard Business Review 61:8-10,16 (Sept.-Oct. 1983).

34. Lammers, "Power and Participation in Decision-making in Formal Organizations," p.203.

35. Ibid.

36. John Forester, "Bounded Rationality and the Politics of Muddling Through," Public Administration Review 44:23-31 (Jan./Feb. 1984); and Anna Grandori, "A Prescriptive Contingency View of Organizational Decision Making," Administrative Science Quarterly 29:192-209 (June 1984).

37. Douglas Zweizig, "The Informing Function of Adult Services in Public Libraries," RQ 18:240-44 (Spring 1979).

38. An attempt was made to survey all articles on relevant subjects that appeared in major library journals from the early 1960 s to date. Citation tracking allowed the author to review the monographic literature as well. Emphasis centered on forms of library governance, organizational structure, decision making, power, and professionalism.

39. Richard Eggleton, "Academic Libraries, Participative Management, and Risky Shift," Journal of Academic Librarianship 5:270-73 (Nov. 1979); and Louis Kaplan, "On Decision Sharing in Libraries: How Much Do We Know?" College \& Research Libraries 38:25-31 (Jan. 1977).

40. Lee Roy Beach and Terrence R. Mitchell, "A Contingency Model for the Selection of Decision Strategies," Academy of Management Review 3:439-49 (July 1978); Grandori, "A Prescriptive Contingency View of Organizational Decision Making;" and Robert S. Runyon, "Some Principles of Effective Decision Making in Academic Libraries," Journal of Academic Librarianship 8:144-50 July 1982), p.146.

41. Keeley, "Impartiality and Participant-Interest Theories of Organizational Effectiveness."

42. Rosemary Ruhig DuMont, "A Conceptual Basis for Library Effectiveness," College \& Research Libraries 41:104 (Mar. 1980).

43. Debra W. Stewart, "Managing Competing Claims: An Ethical Framework for Human Resource Decision Making," Public Administration Review 44:15 (Jan./Feb. 1984).

44. Grandori, "A Prescriptive Contingency View of Organizational Decision Making."

45. Sam E. White, John E. Dittrich, and James R. Lang, "The Effects of Group Decision-making Process and Problem-situation Complexity on Implementation Attempts," Administrative Science Quarterly 25:428 (Sept. 1980).

46. Runyon, "Some Principles of Effective Decision Making in Academic Libraries," p.147-48.

47. Maurice P. Marchant, Participative Management in Academic Libraries (Westport, Conn.: Greenwood, 1976); John M. Roach, Worker Participation: New Voices in Management, Conference Board Report, no.594 (New York: Conference Board, 1973), p.1.; and Prince, "Creative Meetings through Power Sharing."

48. Richard Butler, "Control of Workflow in Organizations: Perspectives from Markets, Hierarchies, and Collectives," Human Relations 36:433 (May 1983); and Barbara B. Moran, Academic Libraries: The Changing Knowledge Centers of Colleges and Universities, ASHE-ERIC Higher Education Research Report, no. 8 (Washington, D.C.: Association for the Study of Higher Education, 1984), p.51-54.

49. Dennis W. Dickinson, "Some Reflections on Participative Management in Libraries," College \& Research Libraries 39:254-55 (July 1978); and Levitan and Johnson, "Labor and Management: The Illusion of Cooperation," p. 8-10.

50. H. Peter Dachler and Bernhard Wilpert, "Conceptual Dimensions and Boundaries of Participation in Organizations: A Critical Evaluation," Administrative Science Quarterly 23:23 (Mar. 1978).

51. Nicholas C. Burckel, "Participatory Management in Academic Libraries: A Review," College \& Research Libraries 45:25-34 (Jan. 1984).

52. David G. E. Sparks, "Academic Librarianship: Professional Strivings and Political Realities," College \& Research Libraries 41:417 (Sept. 1980).

53. Dickinson, "Some Reflections on Participative Management in Libraries," p.258.

54. Lammers, "Power and Participation in Decision-making in Formal Organizations," p. 209-10.

55. Y. K. Shetty, "Management's Role in Declining Productivity," California Management Review 25:33-47 (Fall 1982).

56. Lammers, "Power and Participation in Decision-making in Formal Organizations," p.204.

57. Kaplan, "On Decision Sharing in Libraries"; and J. Todd, "Management Control: A Zero-Sum 
Game?"' Management International Review 4:73 (1978).

58. Joseph A. Alutto and James A. Belasco, "A Typology for Participation in Organizational Decision Making," Administrative Science Quarterly 17:122 (Mar. 1972).

59. Dachler and Wilpert, "Conceptual Dimensions and Boundaries of Participation in Organizations," p.1.

60. Ibid., p.8.

61. P. Bernstein, Workplace Democratization: Its Internal Dynamics (New Brunswick, N.J.: Transaction Books, 1976).

62. Donald V. Nightingale, "Participation in Decision-making: An Examination of Style and Structure and Their Effect on Member Outcomes," Human Relations 34:1130 (Dec. 1981).

63. Keeley, "Impartiality and Participant-Interest Theories of Organizational Effectiveness," p.11; and Ronald L. Cohen, "Procedural Justice and Participation," Human Relations 38:643-63 (July 1985).

64. John F. Witte, Democracy, Authority, and Alienation in Work (Chicago: Univ. of Chicago Pr., 1980), p.160; and Gordon A. Walter, "Organizational Development and Individual Rights," Journal of Applied Behavioral Science 20:423-40 (1984). A special issue entitled "Ethics, Values, and Human Rights."

65. Daniel Yankelovich, New Rules: Searching for Self-fulfillment in a World Turned Upside Down (New York: Random, 1981), p.222.

66. Dachler and Wilpert, "Conceptual Dimensions and Boundaries of Participation in Organizations," p.10.

67. Nightingale, "Participation in Decision-making," p.1119.

68. Dachler and Wilpert, "Conceptual Dimensions and Boundaries of Participation in Organizations," p.10.

69. Nightingale, "Participation in Decision-making," p.1128.

70. John Rohrbaugh, Gary McClelland, and Robert Quinn, "Measuring the Relative Importance of Utilitarian and Egalitarian Values: A Study of Individual Differences about Fair Distribution," Journal of Applied Psychology 65:48 (Feb. 1980).

71. Shetty, "Management's Role in Declining Productivity."

72. Dachler and Wilpert, "Conceptual Dimensions and Boundaries of Participation in Organizations," p.12.

73. Edwards, "The Management of Libraries and the Professional Functions of Librarians," p.151.

74. Prince, "Creative Meetings through Power Sharing," p.52.

75. Dickinson, "Some Reflections on Participative Management in Libraries," p. 255.

76. William R. Torbert, "Educating toward Shared Purpose, Self-Direction and Quality Work," Journal of Higher Education 49:109-35 (1978).

77. Thomas G. Cummings, "Self-regulating Work Groups: A Socio-technical Synthesis," Academy of Management Review 3:625-34 (July 1978).

78. Charles Martell, "Improving the Effectiveness of Libraries through Improvements in the Quality of Working Life," College \& Research Libraries 42:435-46 (Sept. 1981).

79. Charles Martell, The Client-Centered Academic Library: An Organizational Model (Westport, Conn.: Greenwood, 1983).

80. Barry A. Stein and Rosabeth Moss Kanter, "Building the Parallel Organization: Creating Mechanisms for Permanent Quality of Work Life," Journal of Applied Behavioral Science 16:371-17 (Summer 1980); and Neal Q. Herrick, "Parallel Organizations in Unionized Settings: Implications for Organizational Research," Human Relations 38:963-81 (Oct. 1985).

81. Stein and Kanter, "Building the Parallel Organization." Articles calling for new organizational forms have also appeared in the field of education. In a recent article by Toby J. Tetenbaum and Thomas A. Mulkeen, "Designing Teacher Education for the Twenty-First Century," Journal of Higher Education 57:626 (Nov.-Dec. 1986), the authors note that "rigid and efficient organizations are no longer as efficacious as fluid and flexible ones in which experimentation and autonomy can thrive."

82. Robert E. Cole, "The Macropolitics of Organizational Change: A Comparative Analysis of the Spread of Small-Group Activities," Administrative Science Quarterly 30:560-85 (Dec. 1985).

83. Alutto and Belasco, "A Typology for Participation in Organizational Decision Making," p.118.

84. New York Times, Business Section (Feb. 14, 1982), p.1.

85. Chris Argyris, "Personality and Organization Theory Revisited," Administrative Science Quarterly 18:141-67 (June 1973). 